\title{
Selective IgA Deficiency a Probable Risk of Recurrent Chest Infections in Asthmatics
}

\author{
Fawzia Hassan Abo Ali' \\ Nehal Elfawy Mahmoud' \\ Amr Yakout Mohamed \\ El-Sayed' \\ Mariam Fathy Abdelmaksoud ${ }^{2}$ \\ Alaa K Shata ${ }^{3}$ \\ Shaimaa Hani Fouad (DD \\ 'Department of Internal Medicine/Allergy \\ and Clinical Immunology, Ain-Shams \\ University, Cairo, Egypt; ${ }^{2}$ Department of \\ Clinical Pathology, Ain-Shams University, \\ Cairo, Egypt; ${ }^{3}$ Department of \\ Pulmonology, Ain Shams University, \\ Cairo, Egypt
}

Correspondence: Shaimaa Hani Fouad Department of Internal Medicine/ Allergy and Clinical Immunology, Ain Shams University, Abbasia, Cairo, 11566 , Egypt Tel/Fax + 202 24346888;

$\mathrm{Tel}+201 \mathrm{II} 6110004$

Email shaimaahani@med.asu.edu.eg
Background: Selective immunoglobulin A ( $\operatorname{IgA}$ ) deficiency is characterized by a high incidence of both recurrent infections and atopic diseases. Asthma is one of the most common lung diseases affecting around 300 million people worldwide and is associated with risk of serious pneumococcal disease and microbial infections. Multiple studies have attributed this to impaired innate and adaptive immunity in asthmatics. An additional probable hypothesis is the existence of an underlying primary immunodeficiency (PID), such as selective IgA deficiency ( $I$ IgAD).

Aim: To assess the prevalence of selective IgA deficiency and its correlation to recurrent infections in asthmatic patients.

Methods: A case-control study was conducted on 80 subjects who were divided into 3 groups: 20 Asthmatic patients with recurrent chest infections (Group A), 20 asthmatic patients without recurrent chest infections (Group B) and 40 healthy controls (Group C).

Results: On comparing the 3 studied groups, there was a statistically significant difference between the three groups $(\mathrm{p}=<0.001)$ concerning serum IgA. The mean serum IgA was statistically significantly lower in Group A\&B than in Group C. Furthermore, it was significantly lower in Group A than in Group B and C (p1,2 <0.002 and $<0.001 *$, respectively). The percentage of selective IgA deficiency or partial IgA deficiency in asthmatic patients was $56 \%$ (26 patients). Group A showed a statistically significant higher percentage of selective/partial IgA deficiency.

Keywords: $\operatorname{sg} A$, sIgE, sIgM, sIgG, asthma, recurrent infections, immune deficiency

\section{Introduction}

Asthma is a chronic inflammatory condition of the airways portrayed by its clinical heterogeneity due to the high intricacy of its pathophysiology. Several risk factors predispose to airway hyperresponsiveness and the limitation of the airflow. However, the exact etiology has yet not been fully elucidated. ${ }^{1}$ The role of infections as triggering and exacerbating factors in asthma are widely recognized. The mechanisms underlying increased risk of microbial infections in asthmatic patients are unknown. ${ }^{2,3}$ Recently, studies suggest that asthma is associated with impaired innate ${ }^{4-6}$ and adaptive $^{7}$ immunity, accounting for an increased susceptibility to infection. An additional probable etiology, other than immune inadequacy, for the increased risk of microbial infections in asthmatic patients is the existence of selective IgA deficiency (sIgAD). ${ }^{8}$ Selective immunoglobulin A (IgA) deficiency is characterized by a high incidence of both recurrent infections and atopic diseases. It is defined as an isolated deficiency of IgA less than $0.07 \mathrm{~g} / \mathrm{L}$ in a patient above 4 years old. ${ }^{9}$ When serum $\operatorname{IgA}$ level is more than $7 \mathrm{mg} / \mathrm{dL}$, but two standard deviations beneath normal for age, it is 
called partial IgA deficiency. ${ }^{31}$ The current study aims at investigating the prevalence of selective immunoglobulin A deficiency in Egyptian asthmatic patients and its correlation with recurrent infections in those patients.

\section{Methodology}

\section{Subjects and Setting}

The study was a case-control study which included 80 subjects attending the outpatient clinic of allergy and clinical immunology at Ain Shams University hospital during the period 2019-2020.

Study population: 80 Patients were divided into 3 groups:

1. Group A included 20 Asthmatic patients with recurrent chest infections;

2. Group B included 20 Asthmatic patients without recurrent chest infections;

3. Group $\mathrm{C}$ included 40 healthy controls who fulfill the same exclusion criteria as the patients.

They were health workers recruited from the hospital staff members.

- Recurrent chest infections were defined as the occurrence at least 3 lower respiratory tract infections (viral or bacterial) in a 1-year period, with at least 2 episodes of pneumonia with radiographic evidence (viral or bacterial).

\section{Inclusion Criteria}

1. Age above 18 years old;

2. Mild-to-moderate Asthmatic patients according to GINA 2019.

\section{Exclusion Criteria}

1. Smoking in order to exclude asthmatic bronchitis;

2. Patients with chronic diseases and other causes of secondary immune deficiency which could explain the recurrent chest infections, such as diabetes hypertension, pregnancy and malignancy;

3. Patients taking medications which are known to cause IgA deficiency including anti epileptics Sulfasalazine, D penicillamine, Gold, Thyroxine, Captopril, Levamisole, systemic corticosteroids and Cyclosporine;
4. History of immunosuppressive medications intake that may result in recurrent chest infections;

5. Comorbid conditions that are characterized by selective IgA deficiency such as rheumatoid arthritis, lupus, celiac disease, or inflammatory bowel disease to avoid confounding effect.

\section{Each Patient is Subjected to the Following}

1. Full detailed history and examination to exclude any comorbid condition (diabetes, hypertension, or any other system affection) or any drug intake that affects the results of the study;

2. History of inhaled corticosteroids intake;

3. Full detailed allergic history, and skin prick test to common allergens;

4. Clinical examination of the respiratory system;

5. Chest x-ray was done to exclude other lung pathology;

6. Pulmonary function tests with special emphasis on FEV1, FEV1/FVC to confirm the diagnosis of Asthma using SPIROMETRICS;

7. Serum immunoglobulins for each patient including total serum IgE which was done using enzymelinked immunosorbent assay kit (ELISA) supplied by Bioss, USA, and Serum IgA, IgG, IgM which were tested by immunoturbidimetric assay using Cobas c311 analyzer by Roche Diagnostics, Germany. Anti-immunoglobulin antibodies react with the antigen in the sample to form a complex which is measured turbidimetrically;

8. Measure of total leucocytic count with differential using hematology analyzer LH 750 Beckman Coulter, USA;

9. All patients were on demand short acting reliever inhalers.

\section{Statistical Analysis}

The collected data were processed and coded before being analyzed using the IBM SPSS program (Statistical Package for Social Sciences) for Windows Version 20.0. Qualitative data were presented using numbers and percentages. Quantitative data were presented using means, standard deviations and ranges. The comparison between two groups with qualitative data was done by using Chisquare test. Fisher exact test was used instead of Chisquare test when the expected count in any cell was found less than 5 . The comparison between more than 
two groups with quantitative data and parametric distribution was done by using One Way Analysis of Variance (ANOVA). Pearson's correlation was used to find out relationship between two quantitative variables. The confidence interval was set to $95 \%$ and the margin of error accepted was set to $5 \%$. So, the p-value was considered significant only when it was $<0.05$.

\section{Results}

According to (Table 1), there was a statistically significant difference between Group A and Group C regarding the mean of age (Figure 1). Group $\mathrm{A}$ had a higher mean age than Group C (p2 = 0.022*). Both groups, A and B, were comparable regarding the history of inhaled corticosteroids $(\mathrm{p}=$ 0.077). On comparing Groups A \& B with respect to the duration of asthma and asthma control test results, there were non-significant differences between both groups ( $p=0.659$ and 0.968 , respectively). Regarding total leucocyte count, there was a significant difference between the three groups (overall $\mathrm{p}=<0.001$ ). Group A showed a significantly higher mean total leucocyte count than Group B and Group C (p1<0.001*, p2 $<0.001$, respectively).

Regarding the Eosinophilic count, there was a significant difference between the 3 groups (overall $\mathrm{p}=$ $<0.001$ ). Group A showed a statistically significantly higher mean Eosinophilic count than group C. Besides, the mean Eosinophilic count was statistically significantly higher in group $\mathrm{B}$ than in $\mathrm{C}(\mathrm{p} 3<0.001)$. Nonetheless, there was no statistically significant difference between group $\mathrm{A}$ and $\mathrm{B}(\mathrm{p} 2<0.001, \mathrm{P} 1=0.619$, respectively).

Table 2 summarizes the comparison between the 3 studied groups as per the different serum immunoglobulin levels. According to serum IgE, there was a statistically significant difference between the three groups (overall $\mathrm{p}=$ $<0.001)$. The mean serum IgE was statistically higher in Group A\&B than in controls (Figure 2). The mean value of serum IgE was significantly higher in Group A and B than in Group C (p2,3<0.001 and $<0.001^{*}$, respectively). Yet, there was a non-significant difference between Group A and B (p1 = 0.117).

As per serum IgA, there was a statistically significant difference between the three groups where the mean serum IgA was statistically significantly lower in Group A\&B than in controls (overall $\mathrm{p}=<0.001$ ) as shown, in Table 2 and Figure 3. The mean value of serum $\operatorname{IgA}$ was significantly lower in Group A than in Groups B and in C (p1,2<0.002 and $<0.001^{*}$, respectively). There was a statistically nonsignificant difference between Groups B and C $(\mathrm{p}=1)$.
Furthermore, there was a non-significant difference between the three groups with respect to the mean serum IgM and serum IgG level with a p-value equal to 0.778 and 0.067 , respectively.

Concerning the percentage of selective IgA deficiency or partial IgA deficiency in asthmatic patients, 26 patients $(56 \%)$ of all asthmatic patients had a selective IgA deficiency or a partial deficiency as shown in Table 3. On comparing the percentage of selective IgA deficiency and partial deficiency in Group A\&B, Group A showed a statistically significant higher percentage of selective/ partial IgA deficiency. Seventeen patients in Group A $(85 \%)$ had a selective or a partial IgA deficiency, while 9 patients in Group B (45\%) had a selective or a partial IgA deficiency. Among patients with selective/ partial IgA deficiency in asthmatics, Group A had a significant higher proportion of subject with complete IgA deficiency, while group B had a significantly higher proportion of partial selective IgA deficiency $(p=0.03)$, as shown in Table 3.

Table 4 shows correlations between $\operatorname{IgA}$ and different statistically significant parameters in asthmatic patients. There was a non-significant positive correlation between the duration of asthma and absolute eosinophilic count and Serum IgA, while there was a significant positive correlation between asthma control test and serum $\operatorname{IgA}(\mathrm{r} \mathrm{s}=$ $\left.0.314 \mathrm{p}=0.048^{*}\right)$. As the asthma control test results increased in value there was a corresponding significant increase in serum $\operatorname{IgA}$.

There was a non-significant negative correlation between age and serum $\operatorname{IgA}$ on the one hand and serum $\operatorname{IgE}$ and serum $\operatorname{IgA}$ on the other in asthmatic patients. Nonetheless, there was a significant negative correlation between total leucocytic count and serum $\operatorname{IgA}(\mathrm{r} \mathrm{s}=-0.418$ $\left.\mathrm{p}=0.007^{*}\right)$. As total leucocytic count increased there was a corresponding significant decrease in serum IgA in asthmatic patients, as shown in Figure 4. Moreover, serum IgA level was significantly lower in patients taking inhaled corticosteroids $(\mathrm{p}=0.03)$, as shown in Table 5 and Figure 5.

\section{Discussion}

The current study has reached finding concerning the evaluation of serum IgA level and its correlation to recurrent infections in Asthmatic patients. In addition, the results of this study lend further support to the fact that serum IgE significantly increases in Asthmatic patients. 
Table I Comparison Between the Three Studied Groups According to Demographic Data, Asthma Control, Duration of Asthma, Drug History and CBC Parameters

\begin{tabular}{|c|c|c|c|c|c|c|c|}
\hline & \multicolumn{2}{|c|}{ Group A $(n=20)$} & \multicolumn{2}{|c|}{ Group B $(n=20)$} & \multicolumn{2}{|c|}{ Group $C(n=40)$} & \multirow[t]{2}{*}{ Overall $p$} \\
\hline & No. & $\%$ & No. & $\%$ & No. & $\%$ & \\
\hline \multicolumn{8}{|l|}{ Gender } \\
\hline Male & 7 & 35.0 & 8 & 40.0 & 19 & 47.5 & 0.631 \\
\hline Female & 13 & 65.0 & 12 & 60.0 & 21 & 52.5 & \\
\hline \multicolumn{8}{|l|}{ Age (years) } \\
\hline Min. - Max. & \multicolumn{2}{|c|}{$22.0-45.0$} & \multicolumn{2}{|c|}{$19.0-45.0$} & \multicolumn{2}{|c|}{$27.0-45.0$} & $0.028^{*}$ \\
\hline Mean \pm SD. & \multicolumn{2}{|c|}{$38.85 \pm 6.56$} & \multicolumn{2}{|c|}{$36.15 \pm 8.12$} & \multicolumn{2}{|c|}{$33.85 \pm 6.04$} & \\
\hline Median (IQR) & \multicolumn{2}{|c|}{$40.50(36.0-43.5)$} & \multicolumn{2}{|c|}{$37.0(30.0-44.0)$} & \multicolumn{2}{|c|}{$31.0(29.0-38.0)$} & \\
\hline Sig. bet. Grps & \multicolumn{6}{|c|}{$\mathrm{p}_{1}=0.418, \mathrm{p}_{2}=0.022^{*}, \mathrm{p}_{3}=0.430$} & \\
\hline Inhaled steroids use & No & $\%$ & No & $\%$ & No & $\%$ & Overall $p$ \\
\hline No & 3 & $15.0 \%$ & 8 & $40.0 \%$ & 40 & $100 \%$ & $<0.001^{*}$ \\
\hline Yes & 17 & $85 \%$ & 12 & $60 \%$ & 0 & $0 \%$ & \\
\hline Duration of asthma & \multicolumn{6}{|c|}{$P_{1}=0.077$} & \\
\hline Min. - Max. & \multirow{2}{*}{\multicolumn{2}{|c|}{$\begin{array}{c}4.0-12.0 \\
8.0(6.0-10.0)\end{array}$}} & \multirow{2}{*}{\multicolumn{2}{|c|}{$\begin{array}{c}4.0-12.0 \\
8.0(6.0-9.0)\end{array}$}} & \multirow{2}{*}{\multicolumn{2}{|c|}{-}} & - \\
\hline Median (IQR) & & & & & & & \\
\hline Sig. bet. Grps & \multicolumn{6}{|c|}{$P_{1}=0.659$} & \\
\hline Asthma control test & No & $\%$ & No & $\%$ & No & $\%$ & \\
\hline Poorly controlled $(\leq 19)$ & 6 & 30.0 & 6 & 30.0 & - & - & \\
\hline Partially control (20-24) & 13 & 65.0 & 12 & 60.0 & & & \\
\hline Good control (25) & $\mathrm{I}$ & 5.0 & 2 & 10.0 & & & \\
\hline Min. - Max. & \multicolumn{2}{|c|}{$13.0-25.0$} & \multicolumn{2}{|c|}{$15.0-25.0$} & \multirow{2}{*}{\multicolumn{2}{|c|}{ - }} & - \\
\hline Median (IQR) & \multicolumn{2}{|c|}{$22.0(18.50-23.50)$} & \multicolumn{2}{|c|}{$20.50(19.0-23.50)$} & & & \\
\hline Sig. bet. Grps & \multicolumn{6}{|c|}{$P_{1}=0.968 M C_{P}=1.000$} & \\
\hline Total leucocyte count(thousands/cmm) & & & & & & & Overall $p$ \\
\hline Min. - Max. & \multirow{2}{*}{\multicolumn{2}{|c|}{$\begin{array}{c}10.0-15.90 \\
12.83 \pm 1.84\end{array}$}} & & & & & $<0.001 *$ \\
\hline Mean \pm SD. & & & 7.53 & & & & \\
\hline Sig. bet. Grps & & & $.00 I^{*}, \mathrm{p}_{2}<$ & I., $\mathrm{p}_{3}=0$. & & & \\
\hline Eosinophil $\left(\times 10^{\wedge} 9\right)$ & & & & & & & Overall $\mathrm{p}$ \\
\hline Min. - Max. & & & & & & & $<0.001 *$ \\
\hline Mean \pm SD. & 9.25 & & 7.55 & & & & \\
\hline Sig. bet. Grps & & & $19, p_{2}<c$ & $*, p_{3}<0.0$ & & & \\
\hline
\end{tabular}

Notes: F, F for ANOVA test, Pairwise comparison bet. Each 2 groups was done using Post Hoc Test (Tukey); $\mathrm{H}, \mathrm{H}$ for Kruskal Wallis test, Pairwise comparison bet. Each 2 groups was done using Post Hoc Test (Dunn's for multiple comparisons test); Group A, Asthmatic patients with recurrent chest infections; Group B, Asthmatic patients without recurrent chest infections; Group $C$, healthy controls; Overall $p$, $P$ value for comparing between the studied groups; $P$, $P$ value for comparing between Group $A$ and Group B; $\mathrm{P}_{2}$, P value for comparing between Group A and Group C; $\mathrm{P}_{3}, \mathrm{p}$ value for comparing between Group B and Group C; *Statistically significant at $\mathrm{p} \leq 0.05$.

Abbreviations: $\chi^{2}$, chi square test; MC, Monte Carlo; U, Mann-Whitney test.

Firstly, regarding the correlation between serum IgA and the recurrent infections in asthmatics, asthma is associated with risk of serious pneumococcal disease and microbial infections affecting patients' quality of life. Recent evidence suggests that asthma can influence patients' susceptibility to infections. Yet, research in this domain has been limited. ${ }^{10,11}$ Most previous studies evaluated the prevalence of allergic diseases, especially asthma, among patients having sIgAD $(15 \%$ to $83 \%){ }^{32-34}$ There are, however, limited number of studies which indicate that low or deficient serum IgA levels 


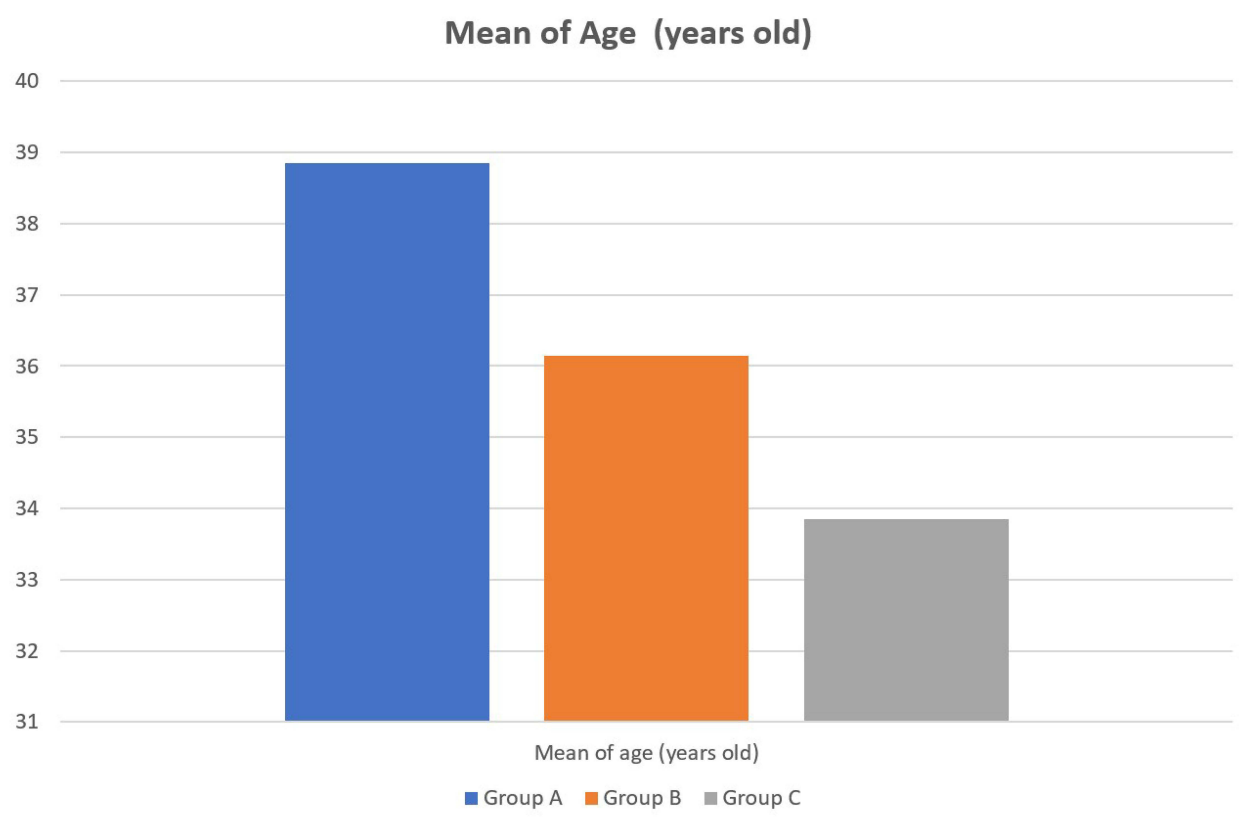

Figure I Comparison between the three studied groups according to Age (years). Group A had a higher mean age than Group $C$ ( $p=0.022$ ). Group A: Asthmatic patients with recurrent chest infections. Group B: asthmatic patients without recurrent chest infections. Group C: healthy controls.

were more common among asthmatics than among nonasthmatics. $^{35,36}$ Based on the results of this study, it was found that there was a statistically significant difference between the three groups (A,B and C) regarding serum IgA where serum IgA level was statistically significantly lower in the asthmatic patients than in the control patients. Besides, serum IgA was statistically significantly lower in the patients with recurrent chest infections than in both asthmatic patients without recurrent chest infections and the healthy controls. Moreover, the percentage of selective /partial IgA deficiency

Table 2 Comparison Between the Three Studied Groups According to Different Serum Immunoglobulin Levels

\begin{tabular}{|c|c|c|c|c|c|}
\hline Serum IgE (IU/mL) & Group A $(n=20)$ & Group B $(n=20)$ & Group C $(n=40)$ & $\mathbf{H}$ & Overall p \\
\hline Min. - Max. & $200.0-800.0$ & $154.0-410.0$ & $20.0-300.0$ & $53.244 *$ & $<0.001^{*}$ \\
\hline Mean \pm SD. & $300.9 \pm 131.8$ & $220.1 \pm 72.0$ & $94.75 \pm 55.35$ & & \\
\hline Sig. bet. Grps & \multicolumn{3}{|c|}{$\mathrm{P}_{1}=0.117, \mathrm{P}_{2}<0.00 I^{*}, \mathrm{P}_{3}<0.00 I^{*}$} & \multirow[b]{2}{*}{ H } & \multirow[b]{2}{*}{ Overall $p$} \\
\hline Serum IgA(mg/dl) & Group A $(n=20)$ & Group B $(n=20)$ & Group C (n = 40) & & \\
\hline Min. - Max. & $6.0-288.7$ & $20-215.0$ & $38.0-329.7$ & $26.55 I^{*}$ & $<0.001 *$ \\
\hline Mean \pm SD. & $84.25 \pm 51.10$ & $179.9 \pm 90.81$ & $219.6 \pm 78.78$ & & \\
\hline Sig. bet. Grps & \multicolumn{3}{|c|}{$\mathrm{P}_{1}=0.002^{*}, \mathrm{P}_{2}<0.00 \mathrm{I}^{*}, \mathrm{P}_{3}=0.100$} & & \\
\hline Serum IgM(mg/dl) & Group A $(n=20)$ & Group B $(n=20)$ & Group C (n = 40) & $\mathbf{F}$ & Overall $p$ \\
\hline Min. - Max. & $45.16-260.7$ & $46.70-247.8$ & $54.69-258.8$ & 0.252 & 0.778 \\
\hline Mean \pm SD. & $146.1 \pm 71.16$ & $137.5 \pm 68.53$ & $150.4 \pm 62.38$ & & \\
\hline Serum IgG (mg/dl) & Group A $(n=20)$ & Group B $(n=20)$ & Group C (n = 40) & $\mathbf{H}$ & Overall $p$ \\
\hline Min. - Max. & $734.8-1630.5$ & $1018.6-1674.9$ & $622.0-14,785.9$ & 5.418 & 0.067 \\
\hline Mean \pm SD. & $1226.1 \pm 253.7$ & $1367.0 \pm 176.4$ & $1709.2 \pm 2127.2$ & & \\
\hline
\end{tabular}

Notes: F, F for ANOVA test; H, H for Kruskal Wallis test, Pairwise comparison bet. Each 2 groups was done using Post Hoc Test (Dunn's for multiple comparisons test); Group A, asthmatic patients with recurrent chest infections; Group B, asthmatic patients without recurrent chest infections; Group C, healthy controls; $p$, $P$ value for comparing between the studied groups; $\mathrm{P}_{1}$, $\mathrm{P}$ value for comparing between Group A and Group B; $\mathrm{P}_{2}$, $\mathrm{P}$ value for comparing between Group A and Group C; $\mathrm{P}_{3}$, $\mathrm{P}$ value for comparing between Group B and Group C; *Statistically significant at $p \leq 0.05$. 


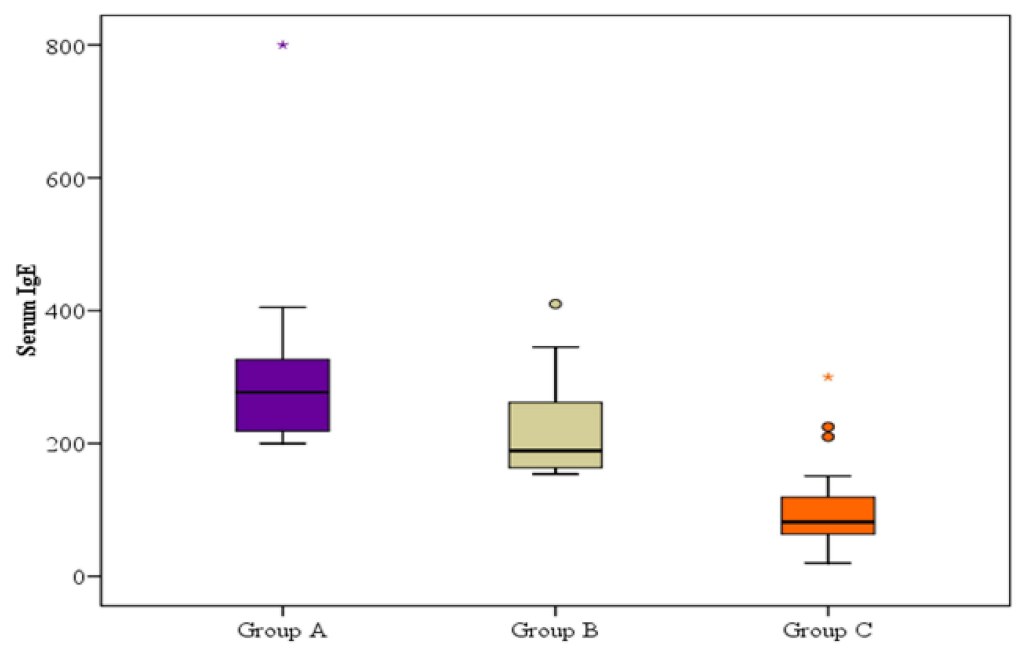

Figure 2 Comparison between the three studied groups according to serum $\lg E \mathrm{IU} / \mathrm{mL}$. The mean serum $\operatorname{lgE}$ was statistically higher in Group $A$ and $B$ than in controls ( $P=$ $<0.00 \mathrm{I})$. The mean value of serum $\mathrm{IgE}$ in Group $\mathrm{A}$ was $300.9 \pm 131.8 \mathrm{IU} / \mathrm{mL}$ while in Group B was $220.1 \pm 72.0 \mathrm{IU} / \mathrm{mL}$ and in the $\mathrm{Group} C \mathrm{Cas} 94.75 \pm 55.35 \mathrm{IU} / \mathrm{mL}$.

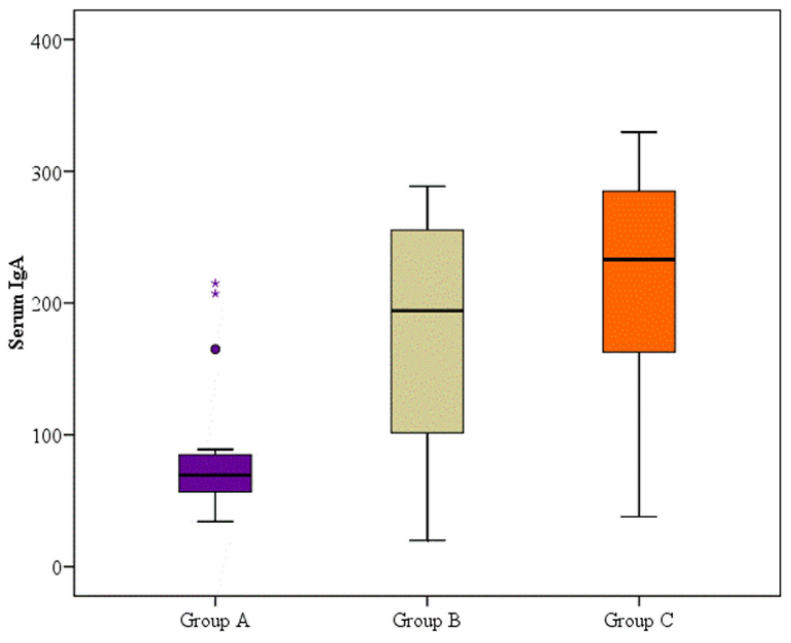

Figure 3 Comparison between the three studied groups according to serum $\lg A$. The mean serum $\lg A$ was statistically significantly lower in Group $A$ and $B$ than in controls $(p=<0.001)$. The mean value of serum IgA in group $A$ was $84.25 \pm$ $51.10 \mathrm{mg} / \mathrm{dl}$ while in Group B was $179.9 \pm 90.81 \mathrm{mg} / \mathrm{dl}$ and in Group C was $219.6 \pm$ $78.78 \mathrm{mg} / \mathrm{dl}$. The mean value of serum $\lg A$ was statistically significantly lower in Group A than in Groups B and C ( $\mathrm{pl}, 2<0.002$ and $<0.00 \mathrm{I}$, respectively). There was a statistically non-significant difference between Groups B and C $(p=1)$. Group A: Asthmatic patients with recurrent chest infections. Group B: Asthmatic patients without recurrent chest infections. Group C: healthy controls.

was statistically significantly high among asthmatic patients where Group A showed a higher statistically significant percentage of selective /partial IgA deficiency than Group B. Group A had a significant higher proportion of subject with complete IgA deficiency, while group $\mathrm{B}$ had a significant higher proportion of partial selective IgA deficiency. Serum IgA showed negative correlations to age, serum IgE level and total leucocytic count, while displaying positive correlations with absolute eosinophilic count, duration of asthma and asthma control test results. The correlations between serum IgA levels and total leucocytic count and asthma control test results were of statistical significance. Moreover, serum IgA level was significantly lower in patients taking inhaled corticosteroids.

The pathogenesis for the association between asthma and SIgAD is undiscovered. Some studies have speculated that the variability of TNFRSF13B molecular deficiency probably shared in the etiopathogenesis of $\operatorname{sigAD} .^{37,38}$ Although the position of TNFRSF13B gene mutations in the development of asthma or allergy is not fully investigated, a recent study revealed that Swedish children with TNFRSF13B mutations were liable to a 2-fold rise in the risk of wheezing at the age of 2 and 4 and a 2.5 -fold increased risk of developing asthma at 4 years of age regardless of serum IgE levels. ${ }^{39}$

On reviewing the studies conducted in the field, it was found that the results of most studies matched our results, while very few did not. Urm et al agree with the current results. They conducted a population-based case-control study to ascertain the correlation between the history of asthma and the diagnosis of selective IgA deficiency (sIgAD)/common variable immunodeficiency (CVID). They concluded that asthmatic patients are more prone to suffer from sIgAD/CVID than non-asthmatic subjects. This correlation may possibly be the reason for the increased risks of bacterial infections in asthmatic individuals. $^{8}$

In addition, Živković et al investigated the association between $\operatorname{sg} \mathrm{AD}$ subtypes and the incidence of respiratory 
Table 3 Comparison Between the Two Studied Groups According to the Percentage of Selective/Partial IgA Deficiency

\begin{tabular}{|c|c|c|c|c|c|c|c|c|}
\hline \multirow[t]{2}{*}{ Serum IgA } & \multicolumn{2}{|c|}{ Total Patients } & \multicolumn{2}{|c|}{ Group A $(n=20)$} & \multicolumn{2}{|c|}{ Group B $(n=20)$} & \multirow[t]{2}{*}{$\chi^{2}$} & \multirow[t]{2}{*}{$\mathbf{p}$} \\
\hline & No. & $\%$ & No. & $\%$ & No. & $\%$ & & \\
\hline Normal & 14 & 35.0 & 3 & 15.0 & II & 55.0 & $7.033^{*}$ & $0.008 *$ \\
\hline Low & 26 & 65.0 & 17 & 85.0 & 9 & 45.0 & & \\
\hline \multirow[t]{2}{*}{ Type of IgA Deficiency } & \multicolumn{2}{|c|}{ Total Patients $(n=26)$} & \multicolumn{2}{|c|}{ Group A $(n=\mid 7)$} & \multicolumn{2}{|c|}{ Group B $(n=9)$} & $\chi^{2}$ & $\mathbf{p}$ \\
\hline & No & $\%$ & No. & $\%$ & No. & $\%$ & & \\
\hline Partial & 10 & $38.5 \%$ & 4 & $23.5 \%$ & 6 & $66.7 \%$ & 4.626 & 0.031 \\
\hline Complete & 16 & $61.5 \%$ & 13 & $76.5 \%$ & 3 & $33.3 \%$ & & \\
\hline
\end{tabular}

Notes: p, p value for comparing between the studied groups; *Statistically significant at $p \leq 0.05$; Group A, asthmatic patients with recurrent chest infections; Group B, asthmatic patients without recurrent chest infections; Group $\mathrm{C}$, healthy controls.

Abbreviation: $\chi^{2}$, chi square test.

Table 4 Summarizes the Correlation Between Serum IgA and Statistically Significant Parameters in Asthmatic Patients

\begin{tabular}{|l|c|c|}
\hline \multirow{2}{*}{} & \multicolumn{2}{|c|}{ Serum IgA } \\
\cline { 2 - 3 } & \multicolumn{2}{|c|}{ Total Patients (n= 40) } \\
\cline { 2 - 3 } & $r_{s}$ & p \\
\hline Age & -0.136 & 0.401 \\
Duration of asthma & 0.209 & 0.195 \\
Total leucocyte count & -0.418 & $0.007^{*}$ \\
Eosinophil $\left(\times 10^{\wedge 9}\right)$ & 0.147 & 0.365 \\
Asthma control test & 0.314 & $0.048^{*}$ \\
Serum IgE & -0.074 & 0.649 \\
\hline
\end{tabular}

Note: *Statistically significant at $\mathrm{p} \leq 0.05$.

Abbreviation: $r_{s}$, Spearman coefficient.

and allergic disorders. They also assessed the connection between the changes in lung functions among children with sIgAD subtypes and respiratory and allergic disorders in a case-control study. Children in the case group were divided into severe sIgAD and partial IgAD patients. Their results revealed that both groups with severe IgAD as well as partial IgAD demonstrated a higher prevalence of allergic diseases and a total number of infections in comparison with controls. Their results are in alliance with the current results. $^{12}$

Likewise, Erkoçoğlu et al evaluated the incidence of allergic diseases and autoimmune disorders among children with sIgAD and their first-degree relatives (FDRs). They revealed that there was an increased incidence of allergic and autoimmune disorders among those patients and their FDRs suggesting a probable common influencing genetic element for SIgAD and autoimmunity in those families. $^{13}$

The negative significant correlation between serum IgA and the total leucocytic count revealed by the current study is attributable to the fact that low serum $\operatorname{IgA}$ levels is associated with recurrent infections in which total leucocytic count is elevated. $^{25-29}$

Shkalim et al evaluated the clinical and immunological characteristics of selective IgA deficiency in children in Israel. They indicated that the percentage of Allergic diseases among those patients was $31.7 \%$ and asthma was the most prevalent, followed by allergic rhinitis. Besides, they concluded that IgA deficiency was one of the immunodeficiencies that might be associated with elevated serum IgE levels and attributed their results to the fact that the increase in serum IgE levels was because of increased mucosal permeability to foreign antigens resulting in enhanced antigen stimulation in patients with IgA deficiency. ${ }^{25}$

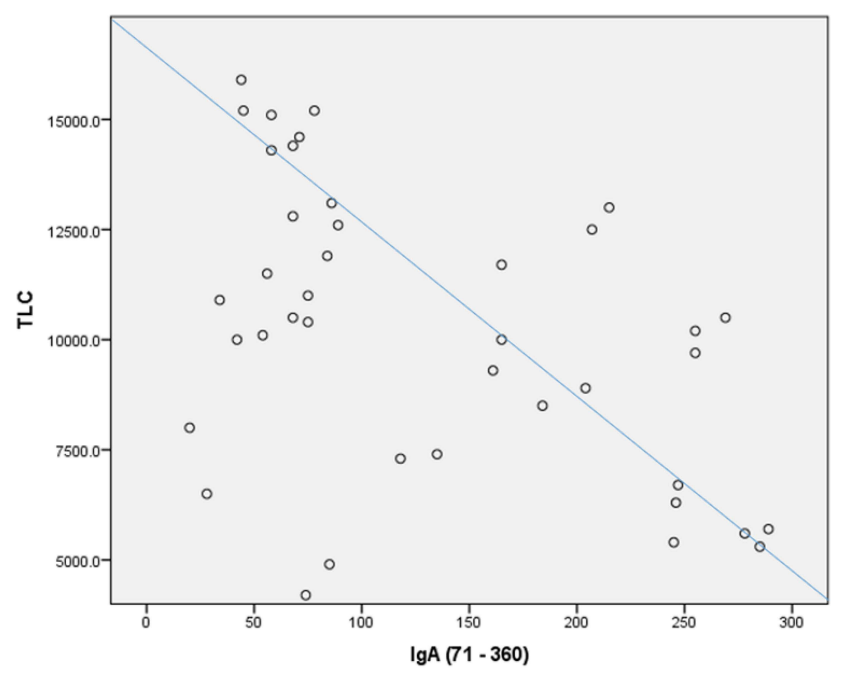

Figure 4 Correlation between serum IgA $(7 \mathrm{I}-360 \mathrm{mg} / \mathrm{dl})$ and Total leucocyte count (TLC). A significant negative correlation between total leucocytic count and serum $\lg A$ was noted $(r s=-0.4 \mid 8 p=0.007)$. As total leucocytic count increased there was a corresponding significant decrease in serum $\lg A$ in asthmatic patients. 
Table 5 Comparison Between Patients Who are Taking Inhaled Corticosteroids and Those are Not with Respect to Serum IgA Level

\begin{tabular}{|l|c|c|c|c|}
\hline $\begin{array}{l}\text { Serum } \\
\text { IgA }\end{array}$ & $\begin{array}{c}\text { Inhaled Steroids } \\
(\mathbf{n}=\mathbf{3 4})\end{array}$ & $\begin{array}{c}\text { No Steroids } \\
(\mathbf{n}=\mathbf{4 7})\end{array}$ & $\mathbf{Z}$ & $\mathbf{P}$ \\
\hline $\begin{array}{l}\text { Median } \\
(\mathrm{IQR})\end{array}$ & $\mathrm{I} 12(57.95-245.55)$ & $\begin{array}{c}192.2(133.4- \\
255.5)\end{array}$ & -2.062 & $0.039 *$ \\
\hline
\end{tabular}

Notes: Wilcoxon Rank Sum Test; *Statistically significant at $p \leq 0.05$.

Similar results were achieved by Shahin et al who revealed an inverse significant correlation between serum IgA levels and serum $\operatorname{IgE}$ levels $(\mathrm{r}=-0.314, \mathrm{p}<0.001)$. However, their study was conducted on a population different from the population of the present study as they investigated the prevalence of IgA deficiency among Egyptian patients with food allergy. ${ }^{24}$

Nonetheless, Kim et al disagreed with the current results regarding the correlation between serum $\operatorname{IgA}$ and serum IgE and age. They declared that serum IgE level was positively related to serum IgA level. They explained their results by suggesting that this correlation was due to the individual variances in functioning plasma cells due to aging or parasitic infestations which increase in adults. ${ }^{23}$ Besides their study revealed a significant positive correlation between the mean age and serum $\operatorname{IgA}(r=0.140, \mathrm{p}=$ 0.000). Their study examined the relationship between serum IgA levels (within the normal range) and sensitization to house dust mites (HDM) or airway hyperresponsiveness (AHR). ${ }^{23}$ They explained this correlation by denoting that repeated infections in adulthood induce a progressive increase in serum IgA levels with age. This disagreement could be due to their large sample size as their study was conducted on 1136 adult patients. Moreover, their study was done on a western population retaining a healthier lifestyle, with lower infection rates in low age groups "Hygiene hypothesis," unlike the current study population.

As for the positive correlation between serum IgA and asthma control test results, several studies agreed with the current results. Balzar et al noticed that the prevalence of moderate/severe Asthma was also significantly inversely related to the IgA level in asthmatics. Moreover, higher sIgA was positively correlated with lung function. Hence, as the degree of asthma severity improved and the patients reached better control, serum IgA level increased. ${ }^{30}$ Similar results were also reached by Kim et al. ${ }^{23}$

In the present study, serum IgA level was significantly lower among patients using inhaled corticosteroids. No previous studies were conducted to assess the effect of inhaled corticosteroids on the serum IgA level. However, Fukushima et al assessed the difference salivary IgA concentration among asthmatic patients who had oral candidiasis and were using inhaled corticosteroids and those who did not have oral candidiasis and also used inhaled corticosteroids. Their results showed that inhaled corticosteroids may potentially reduce salivary IgA. ${ }^{40}$ Their results reinforce the current results.

Secondly, regarding the fact that serum IgE level increases in asthmatic patients, the results of several studies as well as the current one have corroborated it. ${ }^{14-17,20-22}$

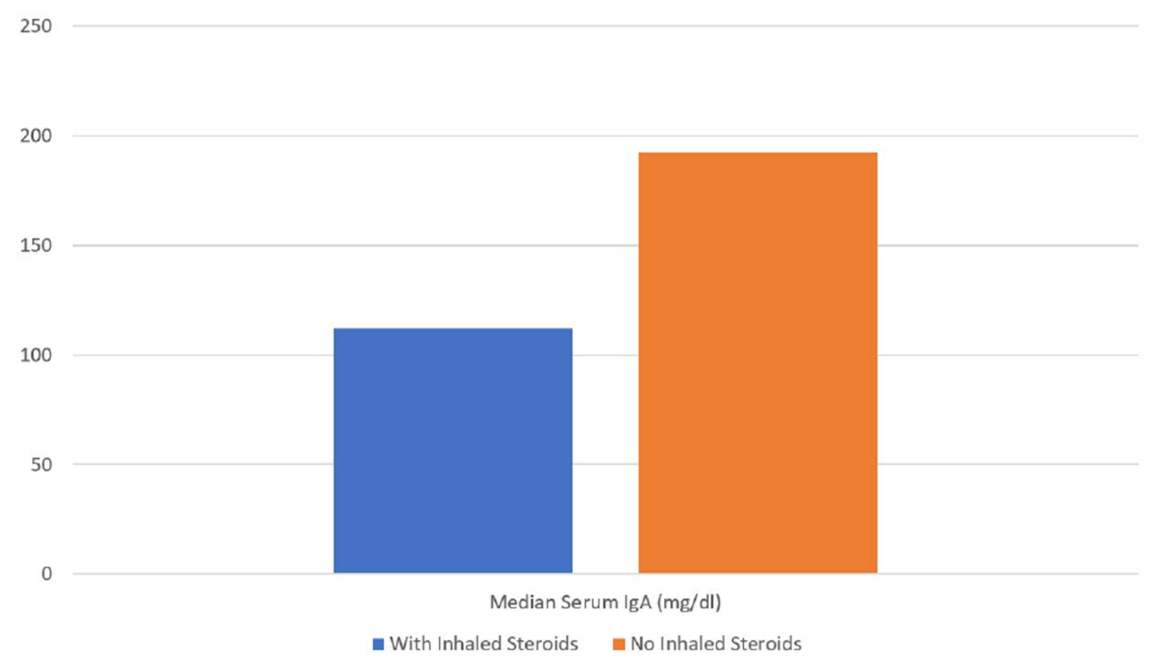

Figure 5 Comparison between patients who are taking inhaled corticosteroids and those are not with respect to serum lgA level. 
Davila et al conducted a multicenter, retrospective, observational study including 383 patients with allergic asthma adult patients. They aimed to evaluate the association between serum total IgE levels and disease severity in adult patients with persistent allergic asthma and to explore the main predictors of IgE levels. They found that serum total $\operatorname{IgE}$ levels in adult patients with persistent allergic asthma were high (two-thirds with levels >150 IU/ $\mathrm{mL}$ ) and extremely variable. ${ }^{19}$

Besides, a retrospective cross-sectional real-life study by Lababidi et al was conducted on 142 patients attending adult refractory asthma outpatient clinic between 2015 and 2018. They investigated the concurrence of high eosinophil count and elevated serum IgE levels in patients with severe refractory asthma and found that serum $\operatorname{IgE}$ and eosinophilic count were concurrently elevated in 110 patients $(78 \%){ }^{18}$

\section{Study Limitations}

One of the limitations of the current study was the small size of its sample. Moreover, it did not assess whether asthmatic patients are predisposed to development of diagnosis of $\operatorname{sgAD}$ in time or whether asthma was a phenotypic subgroup of sIgAD. Moreover, it did not assess the correlation between lung function parameters and serum IgA concentration.

Hence, it is recommended for future research to conduct larger studies to further investigate the association between $\operatorname{sg} \mathrm{AD}$ and asthma and to assess whether asthma is a predisposing factor to $\operatorname{SIgAD}$ or a phenotypic subgroup of sIgAD. Moreover, larger studies assessing the effect of inhaled corticosteroids on serum IgA are also required.

\section{Abbreviations}

IgA, immunoglobulin A; sIgA, serum immunoglobulin A; sIgE, serum immunoglobulin E; sIgG, serum immunoglobulin G; sIgM, serum immunoglobulin M; PID, primary immunodeficiency; sIgAD, selective IgA deficiency; FEV1, forced expiratory volume 1 second; FEV1/FVC, forced expiratory volume 1 second/forced vital capacity ratio; ELISA, enzyme-linked immunosorbent assay; SPSS program, Statistical Package for Social Sciences program; ANOVA, analysis of variance; TNFRSF13B, tumor necrosis factor receptor superfamily member 13B; CVID, common variable immunodeficiency; FDRs, first-degree relatives; HDM, house dust mites; AHR, airway hyperresponsiveness.

\section{Data Sharing Statement}

All the data needed is available upon request.

\section{Ethical Considerations}

Ethical approval of the current study protocol was obtained from the Research Ethics Committee (REC) of Ain Shams University Faculty of Medicine (FWA 00017585). An informed written consent was provided by all participants and their parents. They were informed of the benefits and risks of the study. This study was conducted in accordance with the Declaration of Helsinki.

\section{Acknowledgment}

Sara Ibrahim Taha, MD, Department of clinical pathology, Ain-Shams University, Cairo, Egypt, has revised and edited the manuscript. She did the English editing required by the reviewers and proofread the paper. Shereen Atef Baioumy, MD, Department of Microbiology and Immunology, Zagazig University, Zagazig, Egypt, shared in statistical analysis and performed the laboratory investigations.

\section{Author Contributions}

All authors made a significant contribution to the work reported, whether that is in the conception, study design, execution, acquisition of data, analysis and interpretation, or in all these areas; took part in drafting, revising or critically reviewing the article; gave final approval of the version to be published; have agreed on the journal to which the article has been submitted; and agree to be accountable for all aspects of the work.

\section{Funding}

The authors received no financial support for the research, authorship and/or publication of this article.

\section{Disclosure}

The authors declare no potential conflicts of interest with respect to the research, authorship and/or publication of this article.

\section{References}

1. Busse WW, Lemanske RF. Asthma. N Engl J Med. 2001;344:350-362. doi:10.1056/NEJM200102013440507

2. Patella V, Santus $P$, Puggioni $F$, et al. Is mild asthma in real life always in the Green Zone? Minerva Med. 2014;105(Suppl 2):1-6.

3. Patella V, Bocchino M, Steinhilber G. Asthma is associated with increased susceptibility to infection. Minerva Med. 2015;106(4 Suppl 3): $1-7$. 
4. Marenholz I, Kerscher T, Bauerfeind A, et al. An interaction between filaggrin mutations and early food sensitization improves the prediction of childhood asthma. J Allergy Clin Immunol. 2009;123 (4):911-916. doi:10.1016/j.jaci.2009.01.051

5. Weidinger S, O’Sullivan M, Illig T, et al. Filaggrin mutations, atopic eczema, hay fever, and asthma in children. J Allergy Clin Immunol. 2008;121(5):1203-1209. doi:10.1016/j.jaci.2008.02.014

6. Habibzay M, Saldana JI, Goulding J, et al. Altered regulation of Toll-like receptor responses impairs antibacterial immunity in the allergic lung. Mucosal Immunol. 2012;5(5):524-534. doi:10.1038/mi.2012.28

7. Schneider LC, Weinberg A, Boguniewicz M, et al. Abnormal immune response to varicella vaccine in subjects with atopic dermatitis compared to non-atopic controls. J Allergy Clin Immunol. 2008;121(2 suppl 1):S272-S273. doi:10.1016/j.jaci.2007.12.1080

8. Urm SH, Yun HD, Fenta YA, et al. Asthma and risk of selective IgA deficiency or common variable immunodeficiency: a population-based case-control study. Mayo Clin Proc. 2013;88 (8):813-821. doi:10.1016/j.mayocp.2013.05.021

9. Odineal DD, Gershwin ME. The epidemiology and clinical manifestations of autoimmunity in selective IgA deficiency. Clin Rev Allergy Immunol. 2020;58:107-133. doi:10.1007/s12016-019-08756-7

10. Papi A, Brightling C, Pedersen SE, et al. Asthma. Lancet. 2017;391 (10122):783-800. doi:10.1016/S0140-6736(17)33311-1

11. Lambrecht BN, Hammad H. The immunology of asthma. Nat Immunol. 2015;16(1):45-56. doi:10.1038/ni.3049

12. Živković J, Lipej M, Banić I, et al. Respiratory and allergic disorders in children with severe and partial immunoglobulin A immunodeficiency. Scand J Immunol. 2019;90:e12828. doi:10.1111/sji.12828

13. Erkoçoğlu M, Metin A, Kaya A, et al. Allergic and autoimmune disorders in families with selective IgA deficiency. Turk J Med Sci. 2017;47:592-598. doi:10.3906/sag-1605-50

14. Sunyer J, Anto J, Castellsague J, et al. Total serum IgE is associated with asthma independently of specific IgE levels. The SpanishGroup of the European Study of Asthma. Eur Respir J. 1996;9:1880-1884. doi:10.1183/09031936.96.09091880

15. Freidhoff L, Marsh D. Relationship among asthma, serum IgE levels, and skin test reactivity to inhaled allergens. Int Arch Allergy Appl Immunol. 1993;100:355-61.3. doi:10.1159/000236438

16. Burrows B, Martinez F, Halonen M, et al. Association of asthma with serum IgE levels and skin-test reactivity to allergens. $N$ Engl J Med. 1989;320(5):271-277. doi:10.1056/NEJM198902023200502

17. Sears M, Burrows B, Flannery E, et al. Relation between airway responsiveness and serum $\operatorname{IgE}$ in children with asthma and in apparently normal children. $N$ Engl J Med. 1991;325(15):1067-1071. doi:10.1056/NEJM199110103251504

18. Lababidi HM, AlSowayigh OM, BinHowemel SF, et al. Refractory asthma phenotyping based on immunoglobulin E levels and eosinophilic counts: a real life study. Respir Med. 2019;158:55-58. doi:10.1016/j.rmed.2019.10.003

19. Dávila I, Valero A, Entrenas LM, Valveny N, Herráez L; SIGE Study Group. Relationship between serum total $\operatorname{IgE}$ and disease severity in patients with allergic asthma in Spain. J Investig Allergol Clin Immunol. 2015;25(2):120-127.

20. Global Initiative for Asthma (GINA). GINA report, global strategy for asthma management and prevention; 2019. Available from: https:/ginasthma.org/wp-content/uploads/2019/06/GINA-2019-mainreport-June-2019-wms.pdf. Accessed October 19, 2021.

21. Eger KAB, Bel EH. The emergence of new biologics for severe asthma. Curr Opin Pharmacol. 2019;46:108-115. doi:10.1016/j. coph.2019.05.005

22. Mallah N, Rodriguez-Segade S, Gonzalez-Barcala FJ, et al. Blood eosinophil count as predictor of asthma exacerbation. A meta-analysis. Pediatr Allergy Immunol. 2021;32:465-478.
23. Kim WJ, Choi IS, Kim CS, et al. Relationship between serum IgA level and allergy/asthma. Korean J Intern Med. 2017;32(1):137-145. doi:10.3904/kjim.2014.160

24. Shahin RY, Ali FHA, Melek NAN, et al. Study of selective immunoglobulin A deficiency among Egyptian patients with food allergy. Cent Eur J Immunol. 2020;45(2):184-188. doi:10.5114/ ceji.2020.97907

25. Shkalim V, Monselize Y, Segal N, et al. Selective IgA deficiency in children in Israel. J Clin Immunol. 2010;30(5):761-765. doi:10.1007/ s10875-010-9438-x

26. Wang W, Yao $T$, Zhang $T$, et al. Selective immunoglobulin A deficiency (SIgAD) primarily leads to recurrent infections and autoimmune diseases: a retrospective study of Chinese patients in the past 40 years. Genes Dis. 2020;7(1):115-121. doi:10.1016/j. gendis.2019.10.014

27. Dieguez-Alvarez M, Carballo I, Alonso-Sampedro M, Sopeña B, Gude F, Gonzalez-Quintela A. Serum immunoglobulin-A (IgA) concentrations in a general adult population: association with demographics and prevalence of selective IgA deficiency. Clin Chem Lab Med. 2020;58(4):e109-e112. doi:10.1515/cclm-2019-0957

28. Pakzad H, Sadeghi Z, Houshmand M, Rahvar F. Coronavirus [COVID-19] and IgA deficiency: mini review article. Can J Med. 2020;2(1):13-16.

29. Janzi M, Kull I, Sjöberg R, et al. Selective IgA deficiency in early life: association to infections and allergic diseases during childhood. Clin Immunol. 2009;133(1):78-85. doi:10.1016/j. clim.2009.05.014

30. Balzar S, Strand M, Nakano T, Wenzel SE. Subtle immunodeficiency in severe asthma: igA and IgG2 correlate with lung function and symptoms. Int Arch Allergy Immunol. 2006;140:96-102. doi:10.1159/ 000092252

31. Yel L. Selective IgA deficiency. J Clin Immunol. 2010;30(1):10-16. doi:10.1007/s10875-009-9357-x

32. Edwards E, Razvi S, Cunningham-Rundles C. IgA deficiency: clinical correlates and responses to pneumococcal vaccine. Clin Immunol. 2004;111:93-97. doi:10.1016/j.clim.2003.12.005

33. Aghamohammadi A, Cheraghi T, Gharagozlou M, et al. IgA deficiency: correlation between clinical and immunological phenotypes. J Clin Immunol. 2009;29:130-136. doi:10.1007/s10875-008-9229-9

34. Grumach AS, Jacob CM, Pastorino AC. IgA deficiency: clinical and laboratory evaluation of 60 patients from the "Instituto da Crianca". Rev Assoc Med Bras. 1998;44:277-282.

35. Grundbacher FJ, Massie FS. Levels of immunoglobulin G, M, A, and $\mathrm{E}$ at various ages in allergic and nonallergic black and white individuals. J Allergy Clin Immunol. 1985;75:651-658. doi:10.1016/ 0091-6749(85)90089-2

36. Estrella L, Patel C, Forbes L, et al. Asthma and steroid use in 462 survey respondents with primary immune deficiency on IVIg. J Allergy Clin Immunol. 2008;121:S83. doi:10.1016/j. jaci.2007.12.333

37. Castigli E, Wilson SA, Garibyan L, et al. TACI is mutant in common variable immunodeficiency and IgA deficiency. Nat Genet. 2005;37:829-834. doi:10.1038/ng1601

38. Rachid R, Castigli E, Geha RS, et al. TACI mutation in common variable immunodeficiency and IgA deficiency. Curr Allergy Asthma Rep. 2006;6:357-362. doi:10.1007/s11882-996-0004-9

39. Janzi M, Melen E, Kull I, et al. Rare mutations in TNFRSF13B increase the risk of asthma symptoms in Swedish children. Genes Immun. 2012;13:59-65. doi:10.1038/gene.2011.55

40. Fukushima C, Matsuse H, Saeki S, et al. Salivary IgA and oral candidiasis in asthmatic patients treated with inhaled corticosteroid. J Asthma. 2005;42(7):601-604. doi:10.1080/02770900500216259 


\section{Publish your work in this journal}

The Journal of Asthma and Allergy is an international, peer-reviewed open-access journal publishing original research, reports, editorials and commentaries on the following topics: Asthma; Pulmonary physiology; Asthma related clinical health; Clinical immunology and the immunological basis of disease; Pharmacological interventions and

Submit your manuscript here: https://www.dovepress.com/journal-of-asthma-and-allergy-journal new therapies. The manuscript management system is completely online and includes a very quick and fair peer-review system, which is all easy to use. Visit http://www.dovepress.com/testimonials.php to read real quotes from published authors. 